\title{
International Journal of Arts and Humanities (IJAH) Ethiopia
}

Vol. 8 (4), S/No 31, SEPTEMBER, 2019: 56-65

ISSN: 2225-8590 (Print) ISSN 2227-5452 (Online)

DOI: http://dx.doi.org/10.4314/ijah.v8i4.5

\section{Rationality and Normativity: A Defence of the Metaphysical Foundation of Social and Ethical Values}

\author{
Ezedike, Edward Uzoma PhD \\ Department of Philosophy \\ University of Port Harcourt, Port Harcourt \\ Rivers State, Nigeria \\ E-mail: edward.ezedike@ uniport.edu.ng \\ Tel: +2348032684202 \\ Amadi, ThankGod Bekweri \\ Department of Philosophy \\ University of Port Harcourt, Port Harcourt \\ Rivers State, Nigeria
}

\begin{abstract}
This paper evaluated the role of metaphysics as the critical determinant of both ethical and social values. It is concerned with the philosophical problem of determining the principle underlying the different value opinions, social interactions, perceptions and judgements. The objective of the paper derives from the main concern of modern theory of value which is to find out the nature and significance of value in society. Consequently, the problem of the relations between value and existence; and value and social realities become of great significance on metaphysical grounds. The method of the study is essentially textual analysis. As a branch of philosophy, metaphysics conducts the most general investigation possible into the nature of reality, what is existence (being), and what (fundamentally distinct) types of thing exist. Some people have the idea that the subject matter of metaphysics is pure speculation with little practical relevance to mankind and society. Against this backdrop, this paper sought to establish the importance of metaphysics in the broader spectrum of human existence. In conclusion, the thesis of this paper is that metaphysics can provide a foundation for ethical and social values and that without metaphysics no rational justification may be given to these values.
\end{abstract}

Key words: Metaphysics, ethics, values, society, person

\section{Introduction}

Copyright (C) International Association of African Researchers and Reviewers, 2012-2019: www.afrrevjo.net Indexed African Journals Online (AJOL): www.info@ajol.info 
It is quite germane to begin the introduction of this paper by drawing our attention to Kant's statement in his work, The Metaphysical Elements of Ethics. In his words: "Those who are accustomed only to physiological explanations will not admit into their heads the categorical imperative from which these laws dictatorially proceed, notwithstanding that they feel themselves irresistibly forced by it" (Kant, 2008:1). The foregoing assertion simply reinforces the thesis of this paper on the foundational and, perhaps, indispensable role metaphysics play in the shaping of socio-ethical values in every human society. We shall first explain some basic concepts that are key to the discourse.

In modern philosophical discourse, we tend to restrict the term 'Metaphysics' to explanations of reality that go beyond empirical or scientific accounts. It is, therefore, significant that a good number of socio-ethical concepts can better be explained from the standpoint of metaphysics. The word 'value' is used in many different senses and carries with it such divergent implications that the task of formulating a definite idea of value is necessary. Being an abstract concept, the term, 'value', has been permissibly employed in a variety of ways. While subjective theories are concerned with finding out the psychological import of valuation, others maintain value as a quality inherent in objects. From the idealist perspective, however, values are self-existent entities. For Fichter, value as an elusive term, but generally what is regarded as good, as desirable, as worthwhile, as a cause worthy of pursuit, worth living for and dying for (1973, p. 323). Moreover, it may be taken to mean the conglomerate or set of institutional ideals cherished by a group of people or an individual (Sogolo 1993, p. 119). Subsumed under this set of values include, ethical values, social values, aesthetic values, cultural values, spiritual values and so on. Ethical values are defined better in terms of set of ideals, standards, expectations and norms which act as the charter for acceptable conduct. On the other hand, social values are collections of what is good, desirable within a given society. They include what people count as socially desirable or worthwhile for the proper functioning of society. In general, value has been defined in terms of many concepts; namely, value as utility, value as pleasure, value as interest and value as intrinsic good (absolute value) or as extrinsic good (instrumental value). It is around this fundamental concept of value as absolute or instrumental that a great deal of axiological controversy revolves. Gupta posits the problem of the relations between value and existence and value and reality is of great relevance on metaphysical grounds $(1978$, p. 6). To address our subject matter in this paper, it might be noted that the human being is the bearer of these values, and therefore, one should ask first: what is the relationship of the human being to metaphysics?

\section{Metaphysics and the Human Person: A Foundational Approach}

It must be made clear that the human being is rooted in that which is investigated by metaphysics. Is man still the 'animal metaphysicum', as in former times? To put the question more exactly we must look to that dimension of the human being which plays the deciding part in ethical-social life and which makes the human being a person. We have to discuss, therefore, whether and how the human being, specifically as person, is distinguished by his openness to metaphysics, and whether and how, according to this openness of the person, the human being has the necessary ethical and social values. We shall begin with men/women as persons with two commonly accepted characteristics. First the person is, as Kant puts it: an end in himself (1988, p. 58). Therefore, it is against his or her being to be used as a mere means to an end; his independence is such that he exists never merely for someone else, but for himself. Secondly, the person is an individual, a single being; as such one stands out inasmuch as he exhibits a characteristic singularity. Accordingly, the person is not a homogeneous indifferent atom of man within the multitude or the mass, able arbitrarily to be replaced by some other atom. Rather the person appears as non-interchangeable and irreplaceable at any given time as this particular

Copyright (c) International Association of African Researchers and Reviewers, 2012-2019: www.afrrevjo.net Indexed African Journals Online (AJOL): www.info@ajol.info 
person; the person is always a singular that cannot be repeated. To the extent the person loses his singularity and with it his individuality, it is possible to take the person as a means for an end, and accordingly to use or consume a person. Of course, the person's singularity and freedom must not be overemphasized, like Sartre did, to the extent that the commonness of human nature disappears (1947, p. 290). Freedom and singularity manifest the individual life of the person, which displays itself in two characteristic features which show more exactly what the person is. The first characteristic is the self-consciousness of the person. One does not lose himself in the other or others, nor does one have a diffused or fuzzy consciousness as does the ego-less animal; instead one lives in a clear consciousness of himself. He has always seized his own self and can therefore say to himself, "I." This agrees with the complete return upon oneself (reditio completa) which Thomas Aquinas assigns to the human being (Lamprecht 180). He observes in the animal merely the beginning of a return to one's self (redire incipit). Accordingly, man comes to himself as a person, or is coming to himself, by himself. He is a person, insofar as he still becomes a person; and he becomes a person insofar as he already is a person. The second characteristic of the person is his freedom to dispose or apply himself/herself. By this characteristic one is not irresistibly handed over to the forces which arise from one's own inner being, or those to one's surroundings. Rather, a person of himself stands back, as it were, from these powers so that he can respond with a yes or a no, can accept or discard what he considers unacceptable. The person is not made to live by powers which overcome him, but lives on the basis of his own decision. In other words, he is not determined as a mere member of the whole of nature, but determines himself within the totality of nature; and on top of that, the person subjects this totality to his own determination in the creation of culture (May \& Sharratt, 1994, p. 2). A person's self-disposing capacity completes the selfconsciousness, inasmuch as it distinctly expresses his independence and also his singularity. The former is without doubt apparent, the latter can be inferred from the fact that freedom develops its own and new initiatives, and does not accept the same fixed pattern.

Our description of a person leads us to the question of whether and how the person is rooted in the metaphysical. The answer can be found through the transcendental method by looking for the reason which makes possible the two characteristic features by which a person can be recognized (Williams 1973, p. 13). In the self-consciousness the person reaches himself and therefore what he truly is; whereas, as long as the person remains in the realm of what he appears to be, or in the mere appearance of himself, and does not reach what he is, he does not truly come to himself and is not with himself or in his self-consciousness. Jung (n.d.), with this in mind, developed the difference between the persona or the role someone plays, and the person someone is (p. 1). What a person really is, or what he himself seems to be, cannot be clear for the person while he remains locked in himself as this limited being. Every limited being discloses itself according to its own relative viewpoints. From this point everything shows itself according to the person's limited perspective, but not in the way it really is. This is the case with an animal which, therefore, can never reach itself or its own "I." Consequently, a person is capable of breaking through to his own being only when he steps beyond himself as this limited, confined being, and breaks through to the unlimited, unconfined Being - itself, which embraces and establishes all that is being and discloses the absolute viewpoint. Only from that viewpoint can a being show itself as it is in truth (Olen, Camp, \& Barry, 2008, p. 4). Because the self-consciousness essentially includes a grasp of one's own being, it presupposes reaching out to the all-inclusive Being-itself and with it the foundation of the metaphysical. The same thing holds for the person's freedom to dispose of himself. The person is subject to the ever-present limiting impulses from within and without. But these are not irresistible as long as the attractive goods are unable to satisfy one's striving, i.e., when such goods, as the material object, a personal striving whose formal object is transcendent. On principle (though not

Copyright (c) International Association of African Researchers and Reviewers, 2012-2019: www.afrrevjo.net Indexed African Journals Online (AJOL): www.info@ajol.info 
factually in every case) the person confronts all limited goods freely. The formal object, which constitutes his striving and willing, is necessarily unlimited. On the other hand, while all being is limited, the willing stretches out to the all-inclusive or unlimited Being-itself which here appears as the good, while in the case of the self-consciousness it becomes effective as the true. Inasmuch as the person himself is a limited being, not only can he freely exercise control over such impulses, but he can also control himself as he accepts and rejects himself, completes or destroys himself which again is possible only by looking to Being-itself. According to this, man's free self-disposition is similar to his self-consciousness insofar as it presupposes reaching out to being-itself, by which the person, according to his two characteristic features or fundamental accomplishment is grounded metaphysically. Without this metaphysical grounding the person would dissolve. One who explicitly rejects the metaphysical dimension of the person is continuously implicitly refuted through the very accomplishment of his personal life (Lotz 2012, p. 6).

\section{Metaphysics and Ethical Values: Establishing a Nexus}

Now that the foundational metaphysical structure of the person has been established, we can through its help develop the connection between metaphysics and ethical values. In the person, the order of morality is set off from the order of nature. In the sub-human order of nature all proceedings play themselves out according to the unavoidability of a "must". This does not change because of the in-determined relationships in the microphysical realm, whence comes even the least statistical necessity in the macro-physical realm. In contrast to that order the ethical order is distinguished by the "ought" which contains and manifests freedom. Certainly, the "ought" has a certain binding force; this however does not exclude, but opens toward freedom because when a certain action is demanded one is capable of doing the opposite (Landau, 2012, pp. 3-17). The action does not happen by itself or with the necessity of nature, but only through freedom. Since only the person possesses freedom, the moral order has an essentially personal stamp, while the order of nature is one of the impersonal or of "things." On closer inspection, the natural and the ethical orders in man co-penetrate: his personal life is imbedded in pre-personal happenings. In the child, the latter is first preponderant; while the former emerges from it gradually. In the mature man, at the high point of his life, the personal reaches its fullness. Not all human beings reach the same level of maturity, for freedom is the possibility of either taking freedom up to use and develop it, or withdrawing from it, not using it and so letting it spoil. With regard to the last alternative, however, and except for psychological disorders, no one can completely suffocate his freedom, although he can continue to let himself be driven by impersonal or unfree forces. In this regard, also, although ethical action is not so manifest, one who is ethically undeveloped falls behind the fullness of his humanness and becomes compulsive for lack self-identity and personal independence. For the person freedom is that capacity for self-determination which essentially imparts a certain directedness along with human obligation or "ought". Against this, Sartre sees freedom as the complete absence of determinateness so that man has no pre-impressed essence or pre-given value order (1947, p. 290). He is only what he makes himself to be through his freedom. As this would lead to chaotic arbitrariness Sartre adds that everyone has his own freedom to work out an agreement with the freedom of all others. This contradicts his initial statement on freedom as the absence of determinateness by introducing determinateness or directedness into human freedom. Indeed, a certain essence has been stamped into man by his freedom, which singles him out from all sub-human beings, namely, the quality of standing out from, or of standing in Being-itself. Heidegger points to this when he says: The essence of "being-there" (Da-sein) is "ex-istence" (Ek-sistenz). This essence does not destroy freedom, as Sartre thinks, but stands at its very root (Stumpf \& Fieser, 2003, p. 454). From this same essence springs the

Copyright (C) International Association of African Researchers and Reviewers, 2012-2019: www.afrrevjo.net Indexed African Journals Online (AJOL): www.info@ajol.info 
directedness which is essentially interwoven with freedom, or the binding "ought" which demands that freedom shape one's life inasmuch as the person's freedom is not forced to do this. The different aspects of this essence and work of life-formation have their manifold values which attract our freedom and which, in turn, freedom has to realize. Since the person as free is founded in the metaphysical and requires fixed ethical values, these values also have their roots in the metaphysical, without which the ethical would not exist.

\section{The Role of Motivation and Conscience in Ethical Life}

It should be noted that ethical action is related not to what is determined (determination) but to motivation. While what is determined denotes an influence which excludes freedom, motivation weighs the reasons which speak for or against a certain action, and which go back to the values that always are considered. This weighing of reasons does not lessen freedom, but leads to its completion, because it does not replace one's decision, but prepares for it and makes a pertinent decision possible. Only from such weighing or pondering could there emerge a truly personal action which depicts the individuality of a free person, usually known as a human act (actus humanus). The unconsidered deed, however, which shoots forth without the participation of freedom, is similar to impersonal happenings and is called an act of man (actus hominis) because, though it comes from man, it does not do so in a way that is proper to man (Lotz 2012, p.12). The preceding paragraph shows clearly how motivation attaches itself to the directedness dwelling in freedom, and how it concretizes this directedness for the here and now. Accordingly, ethical action develops itself from motivation: through weighing reasons or values it becomes truly free or personal and enables the metaphysical dimensions of the person to pervade everyday life. It is by conscience that we grasp the ought dwelling within freedom and concretize it in individual behaviour (Timmons, 2001, p. 2). It has its origin neither exclusively in the super-ego, nor in one's environment, as one often hears today. Its word comes from the depths of the person, where one becomes aware of what he is and what he, therefore, ought to be or act (Pojman, 1999, pp. 83-88). In other words, in our conscience we meet our own being as our task or mission both as it spans our whole lifetime and as it stamps us for the present hour. Because of this root, the conscience is imperturbable and capable of recalling itself to itself when it strays from its own track. In specific cases, the conscience can be mature or immature, clean or unclean, alive or dead and consequently clear or hazy, soft or hardened, false or true (Strong 2001, p. 139). One lives without a conscience when one has silenced it or goes against its unmistakable warnings. One acts according to one's conscience to the degree one faithfully follows its lead and so reaches one's true goal or life-truth. In this he avoids and overcomes his life-lie, into which the conscience-less person throws himself. Both the person with conscience and the person without a conscience remain in the ethical realm, for the person can never leave that. But only the one with a good conscience realizes the ethical dimension according to his own proper character, while the one without a good conscience cannot get out of his peculiar perversion (Lotz, 2012, p. 5). Inasmuch as conscience continuously accompanies the person and derives from the very depths of man, at its roots it reaches the metaphysical or has a deeply metaphysical imprint, without which it would evaporate.

\section{Ethical Bond and Unconditioned Obligation}

Let us examine more in detail that by which the ethical bond surpasses other bonds or the nature of the "ought" which, through one's conscience, makes demands upon us. Briefly, this "ought" distinguishes itself through its unconditionality. Only one conditional bond can be expressed in the entire length of the 'if-then' statement: if you want to reach this goal, you will have to use the means necessary for it, just as the vocation of the physician requires a special education (Groarke, 2011, p. 187). In this and in similar cases, the bond is merely conditional, because

Copyright (C) International Association of African Researchers and Reviewers, 2012-2019: www.afrrevjo.net Indexed African Journals Online (AJOL): www.info@ajol.info 
one has to make use of the means only if one wishes to reach one's goal, and no other means will bring this about. In contrast, the ethical "ought" imposes upon man an unconditional bond independent of every other bond, that is, it has value under any condition and the bond cannot be lifted (Driver 2006, p. 2). This unconditionality shows itself in the case of one's faithfulness to conscience, in the case of one's respect for human dignity, and in the case of the objectionableness of slander or of the misuse of the person as a mere means to an end (Copp, 2007, p.10). The person who in such cases goes back to an 'if-then' connection, covers up all that is conditional or all the previously considered givens. Certainly, one could formulate the proposition that man must follow his "ought" only if he wishes to act ethically or to lead an unobjectionable life. However, that formulation differs essentially from the one mentioned above insofar as the ethically good action is precisely not left up to the discretion of man (as in the case of the physician's vocation). Rather, man is bound by the "ought" itself and is called unconditionally (Lotz 2012, p. 5). In this lies the foundation of all other demands of the ethical order. Today, one often hears it objected against the unconditionality of the ethical ought that it contradicts the historicity of all human actions. According to this, all these regulative norms have only a time conditioned nature and, therefore, a conditional value (Weston, 2001, p. 49). This implies that the unconditional norms valid for all times would be excluded. The same would be said about ethical values, since the norms formulate the binding force given with the values. This objection is overcome by the fact that historicity would abolish itself if everything were subjected to the comings and goings of things in time or if nothing endured through change. If there is to be historicity then the foundation which makes it possible must endure. This foundation corresponds to the human foundation or structure, as was developed above, but it cannot be proven here in detail for scope sake. In the same foundation or structure is rooted both the unconditionality of the ethical ought and the ethical values themselves, as will be made clearer in the following paragraphs. The given, trans-temporal, unconditional kernel of the ethical appears to us solely, but also truly, in completely timed-conditioned realities. Therefore, we can speak of the historical unconditionality of the ethical in which neither of the two elements replaces or disappears into the other (Lotz 2012, p. 6). The ground or basis of possibility of the unconditioned in the ethical obviously cannot be found in the conditional, because the former essentially and incalculably supersedes the latter. Insofar that man is a being that is becoming one is only somewhat conditioned, insofar as Being comes to him only with boundaries inasmuch as it is conditioned by one's essence. Whereas he is a relative being which is becoming or alone in a view peculiar to himself, the unconditioned is characteristic of the absolute standing free from any mere viewpoint. Thus, man can be considered the bearer of unconditionality only if his embeddedness in the all-encompassing Being-itself belongs to his constitution. He is the being-which-becomes constituted through the openness of Being, or he is the relative being which is constituted through the lighting up of the Absolute. In other words, ethical values are grounded in man only insofar as, even in the physical order, he has already reached, and lived on the basis of, the metaphysical (Lotz 2012, p. 6; Uduigwome \& Akpan, 2012, pp. 1-14).

\section{The Basis of Social Values and Social Life}

Closely connected with the ethical values are the social ones. Because many ethical values touch upon the social area, and contrariwise, one's social life has many ethical aspects (Rachels \& Rachels 2009: 2). The statement goes even deeper: ethical and social values grow from the same root. Aristotle had been clear that man is not a simple or isolated entity, but needs to live together with his peers (Ethics, bk 8: 205; Politics 1252al-1256al). Man completes himself only in community and in his association with others, not in separation from them. In the animal kingdom we already find an anticipation of such living together, specifically in what one calls

Copyright (C) International Association of African Researchers and Reviewers, 2012-2019: www.afrrevjo.net Indexed African Journals Online (AJOL): www.info@ajol.info 
by analogy ant and bee colonies (Ezedike, 2009, p. 244). The social life of man essentially exceeds such structures in openness and depth, as can be seen from what was said above about the person, for the person is grounded in the openness of Being-itself, which on account of its fullness embraces everything. This shows boundless openness to be the ultimate ground for all things, reaching a depth that cannot be equalled. In virtue of this same openness of Being the person is as much with himself as he is with others: both poles of this encounter come to the same depth as two communicating tubes. More precisely, the possibilities of communication exceed all boundaries in extent and depth, while from both points of view actually completed communication remains subject to boundaries. As this boundlessness originates because it concerns the openness of Being, so the boundaries arise because man, as a being who is becoming, only participates in this openness. In the communication established for social life both partners are humans and persons. In this process the openness of Being shows itself in both parties as they bring to each other openness which in extent and depth may transcend all boundaries. However, the possibilities thus given are never totally exhausted because both partners cannot exceed the boundaries which exist for all changing beings, even though the partners can push these boundaries further and further away. Their communication becomes progressively richer the more the openness of Being unfolds itself in them and rules their reciprocal exchanges. This points out two complimentary aspects. Each one goes to the other in such a way that he goes over to the other. There is no contradiction here; but for each of the two sides the other is fixed by Being-itself. This opens each partner to the other and at the same time strengthens him in himself so that he does not lose himself in the other. As the same Being both strengthens each of the partners in themselves and opens them to the other person they do not suffocate in their own narrowness. In the measure Being is dissolved, the two sides fail in their meeting with one another, or a contradiction forms between being secure in oneself and going over to the other. Without Being, one either goes to the other in such a way that he is not secure in himself and thus has to lose himself in the other, or he secures himself in such a way that he does not go over to the other and therefore becomes locked up in himself. Since Beingitself is precisely the root of all that is metaphysical, it alone makes possible this communication or meeting between men which is social life (Arnhart, 1987, pp. 1-15).

The different ways in which human beings have contacts with each other can be explained through the openness of Being. One can meet the other as an it, as a 'he', or as a 'you'. Someone treats another as an 'it', or a 'thing', and not as a person, when he takes him or her simply as a thing, and forgets the openness of Being which takes place in him; on this level the person is apt to be misused as a mere means to an end. Someone treats another as a he or she when one in fact respects the person in him and does not degrade him to a thing or to a mere means to an end. However, one may be interested only in the accomplishments of the other and not in the person himself; therefore, this person can be replaced by another who can achieve the same thing. Here the openness of Being remains in the background and does not extend past the mainly material accomplishments to the one who realizes them (Foot, 2001, p. 5). Someone treats the other as a 'you' or 'thou', however, when the person himself, and not his accomplishments, is the focus of attention. This other cannot be replaced and is respected as a person in the fullest sense. Since the openness of Being belongs to the constitution of the person, it becomes the characteristic basis of the relationship, which is thus lifted to its proper 'I-Thou' level. As our presentation shows, if the kind and depth of social relationships cut themselves off from the empowering force of Being and thereby from the metaphysical, then in the measure that these relationships degenerate into the quantifiable the metaphysical dimension is lost. We can come to better understand the significance of this, if we consider certain value-systems which play a decisive role in 'I-Thou' relationships. First, we should consider love which unfolds itself in two ways: a self-referral and a self-freeing love. With the former I meet the

Copyright (c) International Association of African Researchers and Reviewers, 2012-2019: www.afrrevjo.net Indexed African Journals Online (AJOL): www.info@ajol.info 
other for my sake; in the latter I love him or her their sake. Only through this latter love can I proceed to the partner-love relationship in which I go beyond my own horizon and enter that of the other or wish the other well. As Augustine has beautifully formulated it, 'I will that the other be. I say yes to the being of the other and contribute to it, so that he or she becomes more and more the person he is and ought to be (Augustine, 1,8, 28-29; Lotz 2012: 2). According to our earlier discussion, this occurs only when I remain in the horizon of Being-itself, that is, the openness of Being; the metaphysical is the ground that makes true love possible. Accordingly, in the measure love turns itself into self-seeking or hate, the metaphysical is lost or Being is forgotten. Similar things can be said about the confidence which comes out of love. The more deeply human beings love each other, the more they place themselves and their affairs in the hands and heart of the other, confident that nothing will be misused. Herein lies trust in the partner, which presupposes his or her trustworthiness (Hooker, 2000, p. 10). This is possible only insofar as one is unshakable, but because of their limitations all beings are at all times subject to shock. Only Being-itself alone is unshakable, due to its un-limitedness. Therefore, man is unshakable only to the degree he goes beyond himself as a changing being and makes himself one with Being-itself. Consequently, trustworthiness and, with it, confidence-are rooted in the metaphysical. It is similar with faithfulness, by which a person gives himself to another or is at his disposal. He will not leave him even in bad times, but is willing to bear difficulties with him. Often, he will be faithful to the other for a whole life time, even if the other disappoints him (Hornby, 2001, p. 3). Again, as a limited being one is fickle and inconsistent, but can gain strength and consistency to the degree that one takes root in the unlimited being or is grounded in the metaphysical (Garret, 2006, p. 1).

\section{Community and Society: Metaphysical Foundations}

Let us turn now from "I-Thou" relationships to "We relationships" in which community and society realize themselves. For community we will use the example of a nation and for society that of the state. In the state tensions exist between the single person and the all-encompassing totality. Extreme solutions submit one of these two poles totally to the other and result in either liberalism, on the one hand, or totalitarianism, on the other. These can be overcome through a middle way in which the person serves the whole and the whole serves the person. The person serves the whole in order that it be capable of giving to the person the prerequisites for the fulldevelopment of the person (Feinberg, 1973, p. 2). Hence, the person is subordinated to the whole only conditionally. This is proven from the previously developed idea of the independence of the person, who as his own self can never be a mere means to an end. The priority of the person is clear here. This could not be said of the person as a limited and changing being, because in these terms the state would be the greater being surpassing the person. On this account, precedence must come to the state. Correspondingly, priority belongs essentially to the person from the fact that the person is rooted in Being and participates in its absoluteness. The person is thus subordinate to the state only insofar as it is a being which is becoming. It follows that the state can place obligations upon the person and as such be superior to the person only if the state is founded in or participates in the absoluteness of Being. Any absolute character on the part of the state is derived from that of the person, because the state is built on persons (Aristotle, Politics 1260b). Accordingly, the cooperation or the working together of persons and society is possible through the metaphysical; should this disappear everything would fall apart. Authority in the state has the obligation to direct individuals to the common good, so that each one contributes his own share. This power of authority to bind persons together in duty is due to authority's participation in the absolutism of Being. Therefore, those who bear authority, whether in a monarchy, an aristocracy or a democracy, are capable of administering their office suitably only when they do not drown in power but bring themselves

Copyright (C) International Association of African Researchers and Reviewers, 2012-2019: www.afrrevjo.net Indexed African Journals Online (AJOL): www.info@ajol.info 
through to Being; this requires a penetrating purification of all who participate (Lotz 2012, p. 7). In this administration, as Plato showed in his Republic, the most important thing is uncorrupted justice which distributes and assigns duties and rights according to objective data, without letting itself be confused through selfish interests. Only they can do such deeds who add to precise and expert knowledge a high degree of personal maturity.

\section{Conclusion}

From all that has been said in this paper, it is apparent that what we claim as ethical and social values in the community or society essentially rests on the foundation of metaphysics. Without this metaphysical grounding the essence of the human person would dissolve. One who explicitly rejects the metaphysical dimension of the person is continuously implicitly refuted through the very accomplishment of his personal life expressed through these values. Personality having its roots in spirit rather in matter expresses itself primarily in ontological nexus, awareness of their fraternal social bond, espousal of moral goodness which involves the power to offer oneself altruistically and sacrificially in human society.

\section{References}

Aristotle. (1996). The Nicomachean ethics. Harry Rackham, trans. Hertfordshire: Wordsworth Classics.

(1962). Politics. London: Penguin Books.

Arnhart, L. (1987). Political questions: Political philosophy from Plato to Ralws. New York: Macmillan Publishing Company.

Augustine, A. (1996). The confessions of Saint Augustine. New Kensington: Whitaker House.

Campbell, G.A. (2010). Reality and value: An introduction to Metaphysics and essay on the theory of Value. U.S.A: Kessinger Publishing.

Copp, D. (2007). The Oxford handbook of Ethical Theory. New York: Oxford University Press.

Driver, J. (2006). Ethics: The fundamentals. Blackwell Publishers.

Ezedike, E. U. (2002). The individual in an African communal universe. In Uduigwomen, A. F. (Ed). From footmarks to landmarks on African philosophy, 2nd edn. 244-252.

Feinberg, J. (1973). Social Philosophy. New Jersey: Prentice Hall.

Fichter, H. J. (1973). Sociology. Chicago: University of Chicago Press.

Foot, P. (2001). Natural goodness. New York: Oxford University Press.

Garret, B. (2006). What is this thing called Metaphysics? London: Routledge.

Groake, L. (2011). Moral reasoning: Rediscovering the ethical tradition. New York: Oxford: University Press.

Gupta, S. N. (1978). The Indian concept of values. Columbia: South Asia Books.

Hooker, B. (2000). Ideal code, Real World. New York: Oxford University Press.

Hornby, N. (2001). How to be good. New York: Riverhead Books.

Kant, I. (1988). The fundamental principles of the metaphysic of morals. New York: Prometheus Books.

Copyright (C) International Association of African Researchers and Reviewers, 2012-2019: www.afrrevjo.net Indexed African Journals Online (AJOL): www.info@ajol.info 
(2008). The Metaphysical Elements of Ethics. Trans. Thomas Kingsmill. Abbott: AVC Manor.

Lamprecht, S.P. (1955). Our philosophical traditions. New York: Appleton-Century-Crofts.

Lawhead, W. (2002). The voyage of discovery. Belmont: Wadsworth Group.

Landau, R. S. (2012). The Fundamentals of Ethics. New York: Oxford University Press.

Leighton, J.A. (2000). Personality and a metaphysics of value. International Journal of Ethics. Vol 21, No.1:23-36.

Lotz, J. (2012). Metaphysics, ethical and social values. Munich: Germany

May, L and Sharratt, S. C. (1994). Applied ethics: A multicultural approach. Englewood Cliffs, New Jersey: Prentice Hall

Moore, B. M \& Bruder, K. (2002). Philosophy: The power of ideas. New York: McGraw Hill.

Olen, J., Van Camp, J. C. \& Barry, V. (n.d.) Applying ethics: A text with readings. Belmont, CA. Thompson Learning.

Plato. "The Republic". The Dialogues of Plato. trans. B. Jowett. Oxford: Clarendon Press.

Pojmam, L. P. (1999). Ethics: Discovering right and wrong. Belmont, CA: Wadsworth Publishing Company.

Rachels, J. \& Rachels, S. (2009). Elements of Moral Philosophy 6th edn. New York: McGraw Hill. Books.

Sartre, J. P. (1947). Existentialism is a humanism. New York: Philosophical Library.

Sogolo, G. (1993). Foundations of African Philosophy. Ibadan: Ibadan University Press.

Strong, J. (2001). The new strong's exhaustive concordance of the Bible. Nashville, Tennesse: Thomas Nelson.

Stumpf, S. E. \& Fieser, J. (2003). Philosophy: History and problems. Boston: McGraw Hill.

Timmons, M. (2001). Moral theory. Little field: Rowman

Uduigwomen, A. F. \& Akpan, C. O. (2012). Metaphysics: A book of readings. Calabar: Ultimate Index Book Publishers.

Weston, A. (2001). A 21st Century ethical toolbox. New York: Oxford University Press.

Williams, B. (1973). Problems of the self. Cambridge: Cambridge University Press.

Copyright (C) International Association of African Researchers and Reviewers, 2012-2019: www.afrrevjo.net Indexed African Journals Online (AJOL): www.info@ajol.info 